\title{
Demonstration and Partial Characterization of the Interferon-Gamma Receptor on Human Mononuclear Phagocytes
}

Antonio Celada, Rodger Allen, Inmaculada Esparza, Patrick W. Gray, and Robert D. Schreiber

Department of Immunology, Research Institute of Scripps Clinic, La Jolla, California 92037; and Department of Molecular Biology, Genentech, Incorporated, San Francisco, California 94080

\begin{abstract}
Radioiodinated recombinant human interferon-gamma (IFN $\gamma$ ) bound to human monocytes, U937, and HL60 cells in a specific, saturable, and reversible manner. $\mathrm{At}^{\circ} \mathrm{C}$, the different cell types bound 3,000-7,000 molecules of IFN $\gamma$, and binding was of comparable affinity $\left(K_{\mathrm{a}}=4-12 \times 10^{8} \mathrm{M}^{-1}\right)$. No change in the receptor was observed after monocytes differentiated to macrophages or when the cell lines were pharmacologically induced to differentiate. The functional relevance of the receptor was validated by the demonstration that receptor occupancy correlated with induction of Fc receptors on U937. Binding studies using U937 permeabilized with digitonin showed that only $46 \%$ of the total receptor pool was expressed at the cell surface. The receptor appears to be a protein, since treatment of U937 with trypsin or pronase reduced ${ }^{125} \mathrm{I}-\mathrm{IFN} \gamma$ binding by 87 and $95 \%$, respectively. At $37^{\circ} \mathrm{C}$, ligand was internalized, since $32 \%$ of the cell-associated IFN $\gamma$ became resistant to trypsin stripping. Monocytes degraded ${ }^{125} \mathrm{I}-\mathrm{IFN} \gamma$ into trichloroacetic acid-soluble counts at $37^{\circ} \mathrm{C}$ but not at $4^{\circ} \mathrm{C}$, at an approximate rate of 5,000 molecules/cell per h. The receptor was partially characterized by SDS-polyacrylamide gel electrophoresis analysis of purified U937 membranes that had been incubated with ${ }^{125} \mathrm{I}-\mathrm{IFN} \gamma$. After cross-linking, the receptor-ligand complex migrated as a broad band that displayed an $M_{\mathrm{r}}$ of $104,000 \pm 18,000$ at the top and $84,000 \pm 6,000$ at the bottom. These results thereby define and partially characterize the IFN $\gamma$ receptor of human mononuclear phagocytes.
\end{abstract}

\section{Introduction}

Macrophage activation has been defined as a series of functional and biochemical modifications in macrophage populations (14) that are induced by a $T$ cell-derived lymphokine known as macrophage activating factor (MAF). ${ }^{1}$ Previous reports from

This is publication 3833 IMM from the Research Institute of Scripps Clinic.

Address correspondence to Dr. Schreiber, Department of Pathology, Washington University Medical School, St. Louis, MO 63110.

Received for publication 11 February 1985 and in revised form 1 July 1985 .

1. Abbreviations used in this paper: DMEM, modified Eagle's medium; DMS, dimethyl suberimidate $2 \mathrm{HCl}$; DMSO, dimethylsulfoxide; DSS, disuccinimydyl suberate; EGS, ethylene glycol-bis (succinimidyl succinate); FCS, fetal calf serum; FITC, fluorescein isothiocyanate; HPLC, high performance liquid chromatography; HSA, human serum albumin; IFN, interferon; IRU, international reference units; $K_{\mathrm{a}}$, association equilibrium constant; KIU, kallikrein inhibitory units; KPBS, DMEM with

J. Clin. Invest.

(c) The American Society for Clinical Investigation, Inc.

$0021-9738 / 85 / 12 / 2196 / 10 \quad \$ 1.00$

Volume 76, December 1985, 2196-2205 several laboratories, including our own, have shown that gammainterferon (IFN $\gamma$ ) can activate mononuclear phagocytes and may well represent the major type of MAF produced by physiological $T$ cell populations (reviewed in references 5 and 6 ).

These observations have prompted attempts to elucidate the biochemical basis for IFN $\gamma$-dependent cellular responses. Recently, we demonstrated the presence of a specific receptor for IFN $\gamma$ on murine macrophages by its ability to bind ligand in a saturable, reversible, and specific manner (7). We have also shown that receptor occupation is a prerequisite for induction of macrophage tumoricidal activity, Ia antigen expression, or enhancement of intracellular microbicidal activity $(7,8)$, biological activities that are all characteristic of activated macrophages.

In the current communication, we wish to extend these observations to the IFN $\gamma$ receptor of human mononuclear phagocytes. In addition, we report the partial physicochemical characterization of the human monocyte IFN $\gamma$ receptor and describe the ultimate fate of the ligand after receptor binding.

\section{Methods}

Chemicals, media, and reagents. Media, supplements, and buffers used in these experiments were purchased or prepared as previously described $(7,9)$, and were determined to contain $<10 \mathrm{pg} / \mathrm{ml}$ of endotoxin using the Limulus amebocyte lysate assay (Sigma Chemical Co., St. Louis, $\mathrm{MO}$ ). Reagents used specifically for this study were purchased from the following sources: phenylmethylsulfonyl fluoride (PMSF), leupeptin, $4 \beta$ phorbol- $12 \beta$ myristate-1 $3 \alpha$ acetate (PMA), dimethylsulfoxide (DMSO), ATP, and aprotinin were obtained from Sigma Chemical Co.; disuccinimydyl suberate (DSS), ethylene glycol-bis (succinimidyl succinate) (EGS) and dimethyl suberimidate $2 \mathrm{HCl}$ (DMS) were purchased from Pierce Chemical Co., Rockford, IL.

Interferons. Natural human IFN $\gamma$ was induced from partially purified human peripheral blood lymphocytes essentially as described by Blalock et al. (10). Lymphocytes at $6 \times 10^{6}$ cells/ml in RPMI medium containing $1 \%$ fetal calf serum (FCS) were stimulated with $1 \mu \mathrm{g} / \mathrm{ml}$ staphylococcal enterotoxin B (SEB, Sigma Chemical Co.) for $24 \mathrm{~h}$. The resulting culture supernatants were cleared of cell debris by centrifugation and filtration and stored at $-20^{\circ} \mathrm{C}$. This preparation had a specific activity of 1.1 $\times 10^{4}$ international reference units (IRU)/mg.

Escherichia coli-derived recombinant human IFN $\gamma$ was produced as previously described (11) and generously provided by Genentech, Inc. (San Francisco, CA). Two preparations (lots D0002SF and E9026A) were used that had been purified to specific antiviral activity of 6.8 and $2 \times 10^{7} \mathrm{IRU} / \mathrm{mg}$, respectively. IFN $\gamma$ was stored at $4^{\circ} \mathrm{C}$ in phosphatebuffered saline (PBS), pH 6.5.

Human alpha and beta interferons were purchased from Lee Biomolecular Laboratories, San Diego, CA. The unpurified preparations had

potassium-PBS; MAF, macrophage activating factor; NP40, Nonidet $\mathrm{P}$ 40; PAGE, polyacrylamide gel electrophoresis; PMA, phorbol myristate acetate; PMSF, phenylmethylsulfonyl fluoride; SEB, staphylococcal enterotoxin B; WGA, wheat germ agglutinin. 
specific activities of $2.1 \times 10^{5} \mathrm{IRU} / \mathrm{mg}$ for alpha interferon and $1 \times 10^{5}$ $\mathrm{IRU} / \mathrm{mg}$ for beta interferon.

Preparation of radioiodinated IFN $\gamma$. Purified recombinant human IFN $\gamma(57 \mu \mathrm{g})$ was labeled with ${ }^{125} \mathrm{I}$ Bolton-Hunter reagent $(1 \mathrm{mCi})$ (ICN Chemicals, Radioisotope Division, Irvine, $\mathrm{CA})$ for $2 \mathrm{~h}$ at $4^{\circ} \mathrm{C}$ as described (7). Protein associated and free ${ }^{125} \mathrm{I}$ were separated by centrifugation through Biogel P6. Typical preparations displayed specific activities of $8.3 \mu \mathrm{Ci} / \mu \mathrm{g}\left(13 \mu \mathrm{Ci} / 10^{6} \mathrm{IRU}\right){ }^{125} \mathrm{I}-\mathrm{IFN} \gamma$ was further purified by gel filtration on a high performance liquid chromatography (HPLC) system using a $7.5 \times 300-\mathrm{mm}$ Biosil TSK 125 column (Bio-Rad Laboratories, Richmond, CA) (7). Fractions were collected in tubes containing $1 / 10$ vol of heat-inactivated FCS. IFN $\gamma$-specific activities were determined either with a cytopathic effect assay, which used purified vesicular stomatitis virus, human WISH cells, and the National Institutes of Health human IFN $\gamma$ standard, or by IFN $\gamma$-specific radioimmunoassay (Centocor, Inc., Malvern, PA). Values obtained with the two assays were in close agreement. Radioiodinated IFN $\gamma$ was stored at $4^{\circ} \mathrm{C}$ and retained biological activity for at least $2 \mathrm{wk}$.

Monoclonal antibodies. Monoclonal antibodies to recombinant human IFN $\gamma$ (HGI/M6 and HGI/M125) were produced by fusion of immune murine splenocytes with the hypoxanthine, aminoplerin, and thymidine (HAT)-sensitive murine myeloma cell line $\mathrm{P} 3 \times 63-\mathrm{Ag} 8.653$ at a splenocyte/myeloma ratio of 10:1 using a previously described fusion protocol (8). The resulting hybridomas were cloned three times by limiting dilution. Specificity was confirmed by enzyme-linked immunosorbent assay and radioimmunoassays that used recombinant human IFN $\gamma$ as antigen. In functional assays, the antibodies were found to neutralize the antiviral activity of natural human IFN $\gamma$. Purified M6 and M125 were prepared by protein-A chromatography of clone culture supernatants. M6 and M125 are $\operatorname{IgG}_{1}, \kappa$, type antibodies. Monoclonal antibody 543 is specific for the human $\mathrm{C} 3 \mathrm{~b}$ receptor and was produced as described elsewhere (12). Monoclonal anti-CR3 $\alpha$-chain (OKM 10) and $\beta$-chain (60.3) were obtained from Ortho Diagnostics, (Raritan, NJ) and from Dr. Patrick Beatty (Fred Hutchinson Cancer Research Center, Seattle, WA), respectively. Hamster monoclonal antibodies against murine IFN $\gamma$ (H22) were prepared as described previously (8).

Monocytes. Human monocytes were purified by Ficoll-Hypaque centrifugation and centrifugal elutriation. As starting material, mononuclear cell-enriched leukocyte concentrates were used that were obtained from normal donors undergoing lymphocytapheresis on a continuous flow centrifugation machine (model 2297; IBM, Princeton, NJ). $80 \mathrm{ml}$ of concentrate (containing $\sim 10^{8}$ leukocytes) was diluted $1: 1$ with sterile $0.9 \%$ sodium chloride and $4 \mathrm{ml}$ layered into tubes containing $10 \mathrm{ml}$ of Lymphopaque (Nyegaard and Co., Oslo, Norway). After centrifugation for $20 \mathrm{~min}$ at $23^{\circ} \mathrm{C}$ at $800 \mathrm{~g}$, the mononuclear cells were collected, washed, and resuspended in $10 \mathrm{ml}$ of elutriation medium (DMEM) with potassium-PBS (KPBS) containing $0.1 \mathrm{M} \mathrm{NaCl}, 0.002 \mathrm{M} \mathrm{KCl}, 0.01 \mathrm{M}$ $\mathrm{KH}_{2} \mathrm{PO}_{4}, 0.008 \mathrm{M} \mathrm{Na}_{2} \mathrm{HPO}_{4}$, and $250 \mathrm{mg} / \mathrm{ml} \mathrm{U}$. S. Pharmacopeia sterile human serum albumin (HSA) (Armour Pharmaceutical Co., Kankakel, IL) (DMEM-KPBS-HSA). The cells were injected into the loading chamber of an elutriation system (JE-6B Elutriation System, Beckman Instruments, Inc., Palo Alto, CA) and introduced into the separation chamber with $125 \mathrm{ml}$ DMEM-KPBS-HSA buffer at a flow rate of $5 \mathrm{ml}$ / $\mathrm{min}$ and a rotor speed of $2,000 \mathrm{rpm}$. Thereafter, two $100-\mathrm{ml}$ fractions were collected at flow rates of 13 and $15 \mathrm{ml} / \mathrm{min}$, and $1150-\mathrm{ml}$ fractions were collected at flow rates of 16.0, 16.5, 17.0, 17.5, 18.0, 18.5, 19.0, $19.5,20.0,21.0$, and $22.0 \mathrm{ml} / \mathrm{min}$. Monocyte-containing fractions (613) were combined and collected by centrifugation at $400 \mathrm{~g}$ for $10 \mathrm{~min}$. The resulting cell preparation contained $>95 \%$ monocytes as assessed by cytocentrifugation (Cytospin 2, Shandon Instruments, Sewickley, PA) and Giemsa-peroxidase staining (13) and displayed $99 \%$ viability.

Cultured cell lines. The human monocytic cell line U937 (14) and the promyelocytic cell line HL60 (15) were maintained in RPMI supplemented with $2 \mathrm{mM}$ L-glutamine, $50 \mathrm{U} / \mathrm{ml}$ penicillin, $50 \mu \mathrm{g} / \mathrm{ml} \mathrm{strep-}$ tomycin, $1 \mathrm{mM}$ sodium pyruvate, $0.075 \%$ ( $\mathrm{wt} / \mathrm{vol}$ ) sodium bicarbonate, and $10 \%$ heat-inactivated FCS.

Membrane preparations. U937 cells were lysed by nitrogen cavitation and the plasma membranes purified in sucrose gradients using a modi- fication of the method described by Jesaitis et al. $(16,17)$. Briefly, U937 cells $\left(2 \times 10^{9}\right)$ were washed and then suspended in $20 \mathrm{ml}$ of homogenization buffer ( $10 \mathrm{mM}$ Hepes, $0.34 \mathrm{M}$ sucrose, $0.1 \mathrm{mM} \mathrm{MgCl} 2,10 \mathrm{mM}$ EDTA, $1 \mathrm{mM}$ dithiothreitol, $250 \mathrm{mM}$ ATP, and 23 kallikrein inhibitory units (KIU)/ml aprotinin) in a $50-\mathrm{ml}$ polyethylene tube containing a cylindrical stir bar. The cell mixture was placed in a Parr cell disruption bomb (Parr Instruments, Moline, IL) that had been precooled to $0^{\circ} \mathrm{C}$. The stirred cell mixture was equilibrated for $15 \mathrm{~min}$ at $600 \mathrm{psi} \mathrm{N}_{2}$ at $0^{\circ} \mathrm{C}$. After cavitation, $90 \%$ of the starting volume was recovered and the lysate was immediately centrifuged at $1,000 \mathrm{~g}$ for $5 \mathrm{~min}$. The foam residue, which floated on top of the supernatant from this centrifugation, was collected and homogenized with buffer in a Dounce homogenizer and combined with the first low-speed supernatant. The mixture was centrifuged again for $5 \mathrm{~min}$ at $1,000 \mathrm{~g}$. The supernatant of the second centrifugation was collected and layered into tubes containing sucrose gradients prepared with Hepes buffer. The gradients consisted of a 3-ml cushion of $60 \%$ sucrose and a $22-\mathrm{ml}$ linear gradient ranging from 55 to $20 \%$ sucrose. The samples were centrifuged in a Sorval TV 850 vertical rotor (DuPont Co., Newton, CT) at 45,000 rpm $(163,000 \mathrm{~g})$ for $1 \mathrm{~h}$ at $4^{\circ} \mathrm{C}$, and $1.5-\mathrm{ml}$ fractions were collected. Fractions were frozen in liquid nitrogen and stored at $-80^{\circ} \mathrm{C}$. In some experiments, U937 were surface labeled using ${ }^{125} \mathrm{I}$-wheat germ agglutinin (WGA) according to the procedure described by Jesaitis et al. (17).

Binding studies with ${ }^{125}$ I-recombinant IFN . The method used to quantitate cellular binding of IFN $\gamma$ has been described in detail elsewhere (7). In brief, cells were incubated at $4^{\circ} \mathrm{C}$ for $2 \mathrm{~h}$ with varying amounts of radiolabeled human IFN $\gamma$. Free and cell-associated ${ }^{125}$ I-IFN $\gamma$ were separated by centrifugation through pthalate oil. Specific binding was defined as the difference between total binding and the binding that occurred in the presence of a 100 to 1000 -fold excess of unlabeled IFN $\gamma$ (nonspecific binding).

To study binding of IFN $\gamma$ to isolated cell membranes, $200 \mu \mathrm{g}$ of purified $\mathrm{U} 937$ membranes were incubated for $1 \mathrm{~h}$ with varying amounts of ${ }^{125}$ I-IFN $\gamma$ in a total volume of $100 \mu \mathrm{l}$ in RPMI-1640 containing 5\% FCS and 1\% Nonidet P-40 (NP40) (Sigma Chemical Co.). Free and membrane-bound IFN $\gamma$ were separated by ultracentrifugation at $4^{\circ} \mathrm{C}$ in a L8-70 ultracentrifuge (Beckman Instruments, Inc.) for $45 \mathrm{~min}$ at 40,000 $\mathrm{rpm}(154,000 \mathrm{~g})$ using a LP42Ti rotor. Specific binding was quantitated as above.

Binding assays in the presence of digitonin or saponin. Five-million U937 cells were preincubated in $1 \mathrm{ml}$ of assay medium (Hanks' balanced salt solution) containing $10 \mathrm{mM}$ Hepes, $10 \mathrm{mM} \mathrm{N}$-Tris[hydroxymethyl]methyl-2-aminoethane sulfonic acid (TES), and $10 \mathrm{mg} / \mathrm{ml}$ bovine serum albumin (BSA) (U. S. Biochemical Corp., Cleveland, OH), $0.1 \%$ glucose, $1 \mathrm{mM}$ PMSF, and $5 \mu \mathrm{g} / \mathrm{ml}$ of leupeptin, $\mathrm{pH} \mathrm{7.4)} \mathrm{at} 4^{\circ} \mathrm{C}$ for 15 min in the presence or absence of $0.055 \%$ digitonin (Matheson, Coleman and Bell, Norwood, $\mathrm{OH})(18)$ or $0.5 \%$ saponin (Sigma Chemical Co.) (19). Digitonin was added from a stock solution $(14 \mathrm{mg} / \mathrm{ml})$ in absolute ethanol. Control cells for the digitonin experiments received an equal volume of absolute ethanol. Treated cells were then incubated with radiolabeled IFN $\gamma$ either alone or in the presence of excess unlabeled IFN $\gamma$ for $2 \mathrm{~h}$ at $4^{\circ} \mathrm{C}$. Binding was assessed by the centrifugation through oil method.

Preparation of fluorescenated human $\operatorname{Ig} G_{1}$. Fluorescein isothiocyanate (FITC) labeling of a human myeloma IgG1 (generously provided by Dr. H. Spiegelberg, Department of Immunology, Research Institute of Scripps Clinic, La Jolla, CA) was accomplished by incubation of $1 \mathrm{mg} / \mathrm{ml}$ protein with $2 \mathrm{mM}$ FITC (Molecular Probes Inc., Plano, TX) in $10 \mathrm{mM}$ borate buffer, pH 9.7, for $30 \mathrm{~min}$ at $37^{\circ} \mathrm{C}$. Bound and free FITC were separated by gel filtration on a 10-ml Biogel P-6 column (Bio-Rad Laboratories). Protein concentration was determined by the method of Lowry (20).

Quantitation of IFN $\gamma$-dependent induction of Fc receptors. Induction of $\mathrm{Fc} \gamma$ receptors on $\mathrm{U} 937$ was measured with a direct immunofluorescence assay. Three-million U937 in $10 \mathrm{ml}$ of IFN $\gamma$-containing medium were incubated for $48 \mathrm{~h}$ at $37^{\circ} \mathrm{C}$ in T25 tissue culture flasks (3013, Falcon Labware, Oxnard, CA). Cells were harvested and incubated $\left(1 \times 10^{6}\right)$ at $4^{\circ} \mathrm{C}$ for 45 min with $10^{-7} \mathrm{M}$ FITC-labeled human $\mathrm{IgG}_{1}$ in a total volume of $50 \mu$ l. To determine nonspecific binding, cells were preincubated with 
$50 \mu \mathrm{l}$ of $10^{-5} \mathrm{IgG}_{1}$ before addition of fluorescenated ligand. After incubation, cells were washed two times with PBS containing 0.5\% HSA and $10 \mathrm{mM}$ sodium azide. Cellular fluorescence was quantitated by flow cytometry with a FACS IV instrument (Becton-Dickinson \& Co., FACS Systems, Mountain View, CA) using linear amplification. The data are presented as the difference between the fluorescence intensity (mean fluorescence channel number) of cells incubated either with IFN $\gamma$ or medium.

Induction of cellular differentiation. Purified monocytes from normal donors were allowed to mature into macrophages by suspension culture in 50-ml teflon beakers (Nagle Co., Rochester, NY) at $37^{\circ} \mathrm{C}$ in a $5 \% \mathrm{CO}_{2}$ atmosphere (21). Each beaker contained $20 \times 10^{6}$ monocytes in $40 \mathrm{ml}$ of RPMI-1640 supplemented with $5 \times 10^{-2} \mathrm{M}$ 2-mercaptoethanol, 2 $\mathrm{mM}$ L-glutamine, $50 \mathrm{U} / \mathrm{ml}$ penicillin, $50 \mu \mathrm{g} / \mathrm{ml}$ streptomycin, and $10 \%$ autologous serum. Cultures were fed every $3 \mathrm{~d}$. Maturation of $U 937$ cells was induced by $5 \mathrm{ng} / \mathrm{ml}$ PMA and incubation for $5 \mathrm{~d}(22)$. HL60 were differentiated to macrophages by culture with PMA $(5 \mathrm{ng} / \mathrm{ml})$ for $5 \mathrm{~d}$ (23) or to granulocytes by culture with DMSO $(1.25 \% \mathrm{vol} / \mathrm{vol})$ for $5 \mathrm{~d}(24)$.

Monocyte maturation was assessed morphologically by light microscopy and cytochemically by loss of peroxidase positivity. Differentiation in U937 or HL60 was confirmed by induction of C3bi (CR3) and $\mathrm{Fc}$ receptors and conversion of the cells to an adherent population.

Uptake and degradation of IFN . These studies were performed in 6-well tissue culture plates (Costar, No. 3506, Cambridge, MA) that had been preincubated overnight with medium containing $20 \%$ FCS. The wells contained $5 \times 10^{6}$ purified human monocytes and $200 \mathrm{ng}{ }^{125} \mathrm{I}$ IFN $\gamma$ in $1 \mathrm{ml}$ of medium. After various lengths of time at $37^{\circ} \mathrm{C}$, the culture supernatants containing unbound or degraded ${ }^{125}$ I-IFN $\gamma$ were collected. The supernatants were mixed with $500 \mu \mathrm{l}$ of FCS and $1 \mathrm{ml}$ $20 \% \mathrm{TCA}$ at $4^{\circ} \mathrm{C}$ and TCA soluble and insoluble material separated by centrifugation at $4^{\circ} \mathrm{C}$ for $20 \mathrm{~min}$ at $2,000 \mathrm{~g}$. Monocytes were washed at $4^{\circ} \mathrm{C}$, solubilized with $1 \% \mathrm{NP40}$, and counted for the determination of total cell-associated radioactivity. As a control, ${ }^{125} \mathrm{I}-\mathrm{IFN} \gamma$ was incubated at $37^{\circ} \mathrm{C}$ in empty wells, then processed as above. The control levels of TCA soluble counts were subtracted as background from all data points. An increase in TCA-soluble ${ }^{125} \mathrm{I}-\mathrm{IFN} \gamma$ in the absence of cells was never observed.

Cross-linking of membrane components to ${ }^{125} I-I F N \gamma$ and SDS-polyacrylamide gel electrophoresis (PAGE) analysis. $200 \mu \mathrm{g}$ of membrane protein corresponding to $\sim 5 \times 10^{7}$ U937 were incubated with $160 \mathrm{ng}$ ${ }^{125} \mathrm{I}$-IFN $\gamma$ for $2 \mathrm{~h}$ at $4^{\circ} \mathrm{C}$. In parallel, a control tube was incubated with a 100 -fold excess of unlabeled IFN $\gamma$. Membranes were washed by centrifugation in an airfuge (Beckman Instruments Inc.) for 30 min at 25 psi $(120,000 \mathrm{~g})$. Pelleted membranes were resuspended in $45 \mu \mathrm{l}$ of PBS, $\mathrm{pH} 7.3$, and $5 \mu \mathrm{l}$ was added of a $10-\mathrm{mM}$ solution of selected cross-linking agents (DMS, DSS, or EGS) dissolved in DMSO. After incubation for

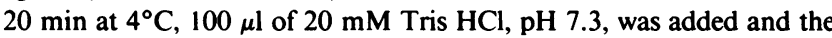
membranes were washed again and resuspended in $50 \mu \mathrm{l}$ of $1 \%$ NP40. After $30 \mathrm{~min}$ at $4^{\circ} \mathrm{C}, 50 \mu \mathrm{l}$ SDS sample buffer was added and membranes were fractionated by SDS-PAGE using 4-12\% polyacrylamide gradient slab gels as described by Laemmli (25). The SDS sample buffer contained $100 \mathrm{mM}$ dithiothreitol. Gels were dried and autoradiography performed at $-70^{\circ} \mathrm{C}$ with XAR-5 film (Eastman Kodak Co., Rochester, NY) and a Cronex Lightning Plus intensifying screen (DuPont Co.). The following proteins were used as molecular weight markers: myosin $\left(M_{\mathrm{r}}=20,000\right)$, $\beta$-Galactosidase $\left(M_{\mathrm{r}}=116,250\right)$, phosphorylase B $\left(M_{\mathrm{r}}=92,500\right)$, BSA $\left(M_{\mathrm{r}}=66,200\right)$, and ovalbumin $\left(M_{\mathrm{r}}=45,000\right)$ (Bio-Rad Laboratories, Chemical Division).

In some cases, whole cells were used as the receptor source. U937 (2 $\times 10^{8}$ cells) were incubated in $5 \mathrm{ml}$ of medium (PBS with $0.20 \mathrm{KIU} / \mathrm{ml}$ of aprotonin and $1 \mathrm{mM}$ PMSF, pH 7.3) containing $200 \mathrm{ng}{ }^{125} \mathrm{I}-\mathrm{IFN} \gamma$ for $2 \mathrm{~h}$ at $4^{\circ} \mathrm{C}$. Cells were washed twice with ice-cold medium and crosslinking was initiated by resuspension of the cells in $5 \mathrm{ml}$ of $1 \mathrm{mM}$ crosslinking reagent. After incubation for $20 \mathrm{~min}$ at $4^{\circ} \mathrm{C}, 10 \mathrm{ml}$ of $20 \mathrm{mM}$ Tris $\mathrm{HCl}, \mathrm{pH} 7.3$, was added and the cells were washed again by centrifugation. Cells were lysed in a Dounce homogenizer and the lysates were centrifuged at $500 \mathrm{~g}$ for $10 \mathrm{~min}$. The supernatants were centrifuged again at $40,000 \mathrm{~g}$ for $30 \mathrm{~min}$ at $4^{\circ} \mathrm{C}$. The high speed pellets were extracted with $100 \mu \mathrm{l}$ of $1 \% \mathrm{NP} 40$ for $30 \mathrm{~min}$ at $4^{\circ} \mathrm{C}$, treated with $100 \mu \mathrm{l}$ of SDS sample buffer, and subjected to SDS-PAGE analysis as above.

\section{Results}

Demonstration of a specific IFN $\gamma$ receptor on Monocytes, U937, and HL60. The IFN $\gamma$ receptor of human mononuclear phagocytes was defined in ligand binding experiments. These studies used radioiodinated recombinant human IFN $\gamma$ that had been subjected to HPLC gel filtration to remove any degraded material that may have formed during storage. As detected by ultraviolet absorption at $280 \mathrm{~nm}$ and radioactivity, IFN $\gamma$ eluted from the column at an $M_{\mathrm{r}}$ of 35,000 (data not shown). $62 \%$ of the recombinant IFN $\gamma$ was recovered after iodination and column purification. The ${ }^{125} \mathrm{I}-\mathrm{IFN} \gamma$ displayed antigenic reactivity with monoclonal anti-IFN $\gamma$ and retained $80 \%$ of its starting specific antiviral activity and $90 \%$ of the capacity to induce Fc receptors on U937.

Fig. 1 shows that ${ }^{125} \mathrm{I}$-recombinant human IFN $\gamma$ binds to peripheral blood human monocytes or U937 in a specific and saturable manner at $4^{\circ} \mathrm{C}$. In these experiments, $96-98 \%$ of the total binding was specific, since it was blocked in the presence of a 100- and 1,000-fold excess of unlabeled IFN $\gamma$, respectively. Binding was homogeneous, noncooperative, and of moderately high affinity. Binding did not require the presence of calcium or magnesium ions. Specific binding of ${ }^{125} \mathrm{I}$-IFN $\gamma$ to HL60, the human promyelocytic cell line, was also demonstrable. Mean values for the receptors on the different cell types are listed in Table I. Whereas the receptors on all three cell types displayed virtually identical association equilibrium constant $\left(K_{\mathrm{a}}\right)$ values, receptor expression on U937 and HL60 was 40-55\% lower than on monocytes. Two different preparations of radiolabeled recombinant IFN $\gamma$ produced similar values.

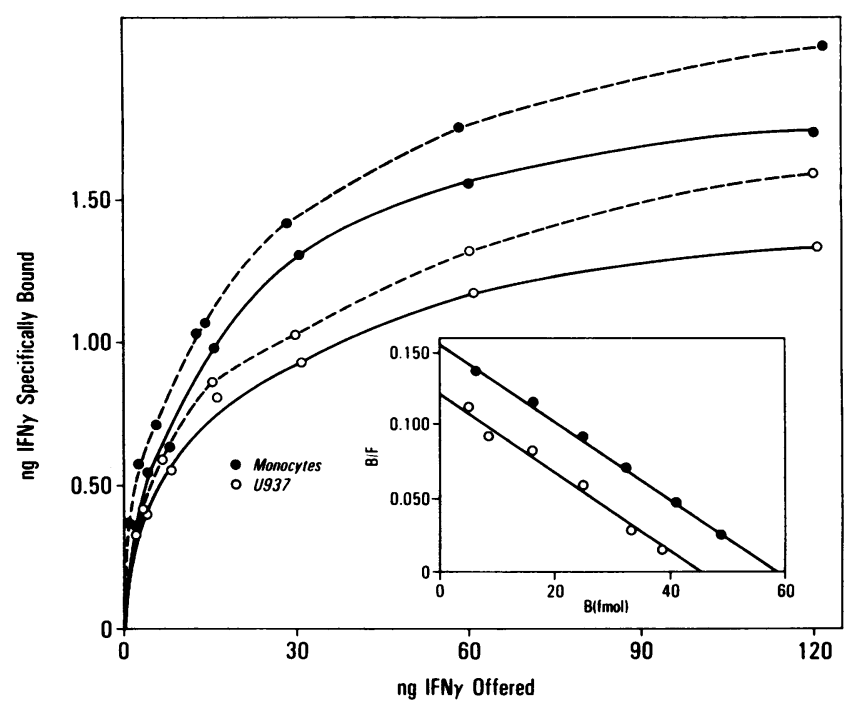

Figure 1. Quantitation of IFN $\gamma$ binding to monocytes and U937. $5 \times 10^{6}$ cells were incubated at $4^{\circ} \mathrm{C}$ for $2 \mathrm{~h}$ with different amounts of radiolabeled, HPLC-purified, recombinant IFN $\gamma$. Cell associated and free ${ }^{125}$ I-IFN $\gamma$ were separated by centrifugation over pthalate oil as outlined in Methods. Specific binding (solid lines) was defined as the difference between total binding (dotted lines) and the nonspecific binding occurring in the presence of a 1,000-fold excess of unlabeled IFN $\gamma$. The inset represents Scatchard analysis of the data. B, bound IFN $\gamma ; \mathrm{F}$, free IFN $\gamma$. 
Table I. Number of IFN $\gamma$ Receptors and $K_{a}$ on Human Monocytes U937 and HL60

\begin{tabular}{clcll}
\hline Cell type & $\begin{array}{l}\text { IFN } \gamma \\
\text { preparation }\end{array}$ & $\begin{array}{l}\text { Number of } \\
\text { experiments }\end{array}$ & Receptors/cell & $\begin{array}{l}K_{\mathbf{a}} \times 10^{-8} \\
\left(\mathbf{M}^{-1}\right)\end{array}$ \\
\hline Monocytes & D 0002 SF & 5 & $6,900 \pm 1,000^{*}$ & $4.0 \pm 2.3$ \\
U937 & D 0002 SF & 20 & $4,200 \pm 1,000$ & $5.0 \pm 3.4$ \\
HL60 & D 0002 SF & 3 & $3,200 \pm 700$ & $4.1 \pm 1.8$ \\
U937 & E 9026 A & 15 & $5,500 \pm 1,600$ & $12.1 \pm 4.7$
\end{tabular}

* Mean \pm SD. Monocytes were obtained from five different normal individuals. The quantitation of IFN $\gamma$ binding was determined as described in Fig. 1.

The specificity of the binding reaction is demonstrated in Fig. 2. Crude preparations of natural human IFN $\gamma$ (SEB-stimulated lymphocyte culture supernatants) efficiently competed with ${ }^{125}$ I-recombinant IFN $\gamma$ for binding to U937 (67\% inhibition was achieved at inputs of 6,800 IRU natural and 2,040 IRU ${ }^{125} \mathrm{I}-\mathrm{rIFN} \gamma$ ). Crude preparations of natural human IFN $\beta$ displayed only a weak ability to inhibit binding of recombinant IFN $\gamma$ when added in large excess (100,000 IRU), while natural human IFN $\alpha$ displayed no inhibitory activity. Lower doses of IFN $\alpha$ or IFN $\beta$ were not inhibitory at all. Monoclonal antibodies (M6 and M125) specific for human IFN $\gamma$, which neutralized IFN $\gamma$ biological activity, abrogated specific IFN $\gamma$ binding to U937. Other monoclonal antibodies that did not react with human IFN $\gamma(\mathrm{H} 22,543, \mathrm{OKM} 10)$ were without effect on the binding reaction.

Fig. 3 demonstrates that the binding of IFN $\gamma$ to U937 was reversible, since bound ligand dissociated from the cells in a homogeneous manner. The $t_{1 / 2}$ for the dissociation was $68 \mathrm{~min}$ at $4^{\circ} \mathrm{C}$ and the reaction could be described by a single dissociation rate constant $\left(k_{\text {off }}\right)$ of $9 \times 10^{-5} \mathrm{~s}^{-1}$.

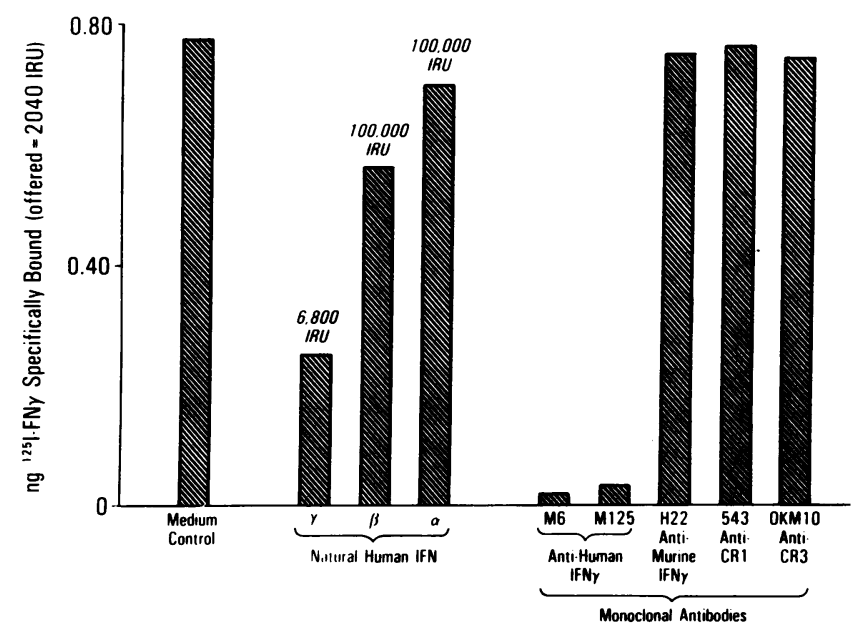

Figure 2. Specificity experiments for recombinant ${ }^{125} \mathrm{I}-\mathrm{IFN} \gamma$ binding to macrophages. U937 cells were preincubated for $30 \mathrm{~min}$ at $4^{\circ} \mathrm{C}$ with designated amounts of competitor in a total reaction volume of 100 $\mu$ l. $20 \mu \mathrm{l}$ of ${ }^{125} \mathrm{I}$-IFN $\gamma(30 \mathrm{ng})$ was then added to each tube and incubation continued for $2 \mathrm{~h}$ at $4^{\circ} \mathrm{C}$. Specific binding and separation of bound and free ${ }^{125} \mathrm{I}-\mathrm{IFN} \gamma$ as in Fig. 1. For these studies, the natural IFN $\gamma$ was concentrated 10 -fold before use by ultrafiltration. A sham supernatant concentrated 10 -fold did not have any inhibitory effect on the ${ }^{125} \mathrm{I}$-IFN $\gamma$ binding to the cells.

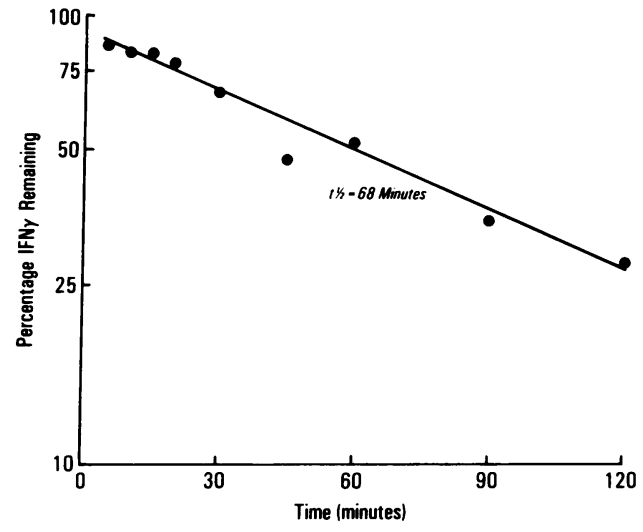

Figure 3. Dissociation of bound IFN $\gamma$ from U937. Sixty-million U937 were incubated in $1 \mathrm{ml}$ of medium containing $800 \mathrm{ng}$ of ${ }^{125} \mathrm{I}$-IFN $\gamma$ for $2 \mathrm{~h}$ at $4^{\circ} \mathrm{C}$. Cells were washed and resuspended to the original volume in the presence of a 100-fold excess of unlabeled IFN $\gamma$. At designated times, aliquots of $5 \times 10^{6}$ cells were centrifuged through phthalate oil and the radioactivity in the cell pellet measured. The data are presented as the log of the percentage of IFN $\gamma$ remaining bound to the cells. Zero time is taken as $100 \%$. The specific IFN $\gamma$ binding at zero time was $0.90 \mathrm{ng} / 5 \times 10^{6}$ cells.

Demonstration that occupation of the IFN $\mathrm{F}$ receptor induces a cellular response. The biological relevance of the receptor was validated by assessing the relationship between receptor occupancy and stimulation of a functional response in mononuclear phagocytes. For this purpose we measured the IFN $\boldsymbol{\gamma}$-dependent induction of Fc receptors on $U 937(26,27)$. Fig. 4 depicts the dose-response profile for Fc receptor induction by purified human recombinant IFN $\gamma .50 \%$ maximal induction was produced by $3 \mathrm{ng}$ of IFN $\gamma$ (60 IRU) and maximal stimulation occurred at $50 \mathrm{ng}$ input (1,000 IRU). When the data from the above experiment and the receptor binding experiments were normalized to similar cell densities (Fig. 4, inset), the concentration of IFN $\gamma$ required for cell binding was found to correlate with that needed to induce the cellular response.

Ontogeny of the IFN $\gamma$ receptor on mononuclear phagocytes. The ability to differentiate U937, HL60, and peripheral blood monocytes in vitro provided a mechanism to study the ontogeny of the IFN $\gamma$ receptor. Table II demonstrates that receptor expression and affinity was not altered when normal peripheral blood monocytes matured to macrophages by $6-8 \mathrm{~d}$ culture in teflon beakers or when U937 and HL60 were differentiated into monocytes/macrophages by $5 \mathrm{~d}$ culture with PMA. No changes in the receptor were noted even when HL60 was induced to become granulocytes by treatment with DMSO.

In all experiments, differentiation was confirmed by morphological, cytochemical, and immunochemical analysis (see Methods). After $5 \mathrm{~d}$ induction with PMA, $>90 \%$ of the U937 and $86 \%$ of HL60 expressed monocyte/macrophage markers and morphology. After $5 \mathrm{~d}$ incubation with DMSO, the HL60 culture consisted of $6.1 \%$ promyelocytes, $65.3 \%$ myelocytes, $24.6 \%$ metamyelocytes, $1.6 \%$ band cells, and $2.4 \%$ mature polymorphonuclear leukocytes.

Protease sensitivity of the IFN $\gamma$ receptor. Pretreatment of U937 with $1 \mathrm{mg} / \mathrm{ml}$ trypsin or pronase for $5 \mathrm{~min}$ at $37^{\circ} \mathrm{C}$ abrogated subsequent binding of ${ }^{125} \mathrm{I}-\mathrm{IFN} \gamma$ at $4^{\circ} \mathrm{C}$ (Fig. 5). Whereas $5 \times 10^{6}$ untreated cells bound $1.4 \mathrm{ng}$ of IFN $\gamma$ at saturation, the same number of trypsin-treated cells bound only $0.18 \mathrm{ng}$ and 


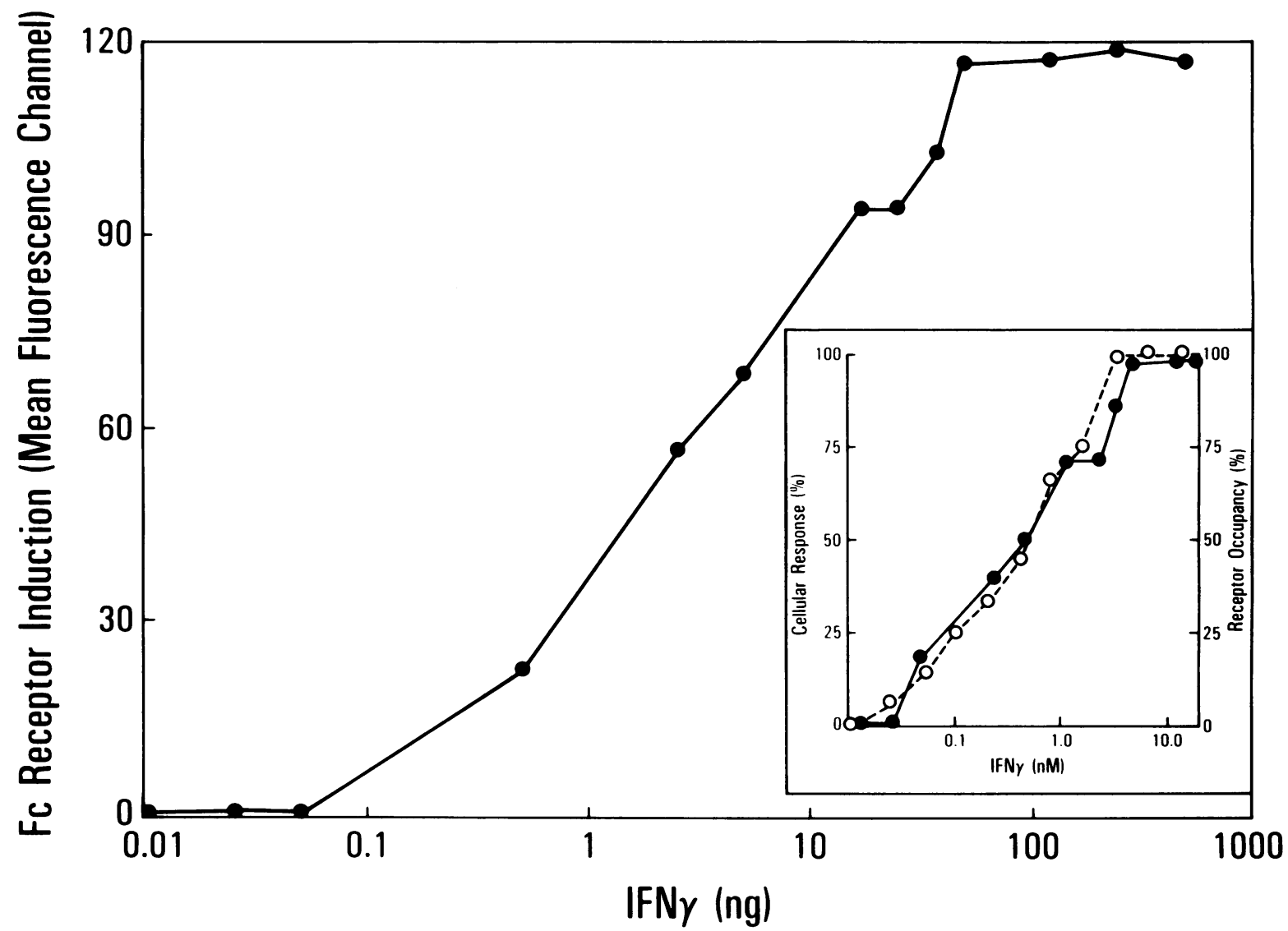

Figure 4. Correlation between IFN $\gamma$ receptor occupancy and induction of $\mathrm{Fc}$ receptor expression on U937. Three-million cells were incubated in $10 \mathrm{ml}$ with various amounts of IFN $\gamma$ for $48 \mathrm{~h}$ at $37^{\circ} \mathrm{C}$. Fc receptors were quantitated by direct immunofluorescence on a flow

pronase-treated cells only $0.07 \mathrm{ng}$ of ligand. These values represent an $87-95 \%$ reduction of IFN $\gamma$ binding and suggest that the receptor is a protein.

Table II. Cellular Differentiation Does Not Alter IFN $\gamma$ Receptor Expression

\begin{tabular}{llll}
\hline Cell type & $\begin{array}{l}\text { Number of } \\
\text { experiments }\end{array}$ & Receptors/cell & $\begin{array}{l}K_{\mathrm{a}} \times 10^{-8} \\
\left(\mathbf{M}^{-1}\right)\end{array}$ \\
\hline $\begin{array}{l}\text { Monocytes: } \\
\quad \text { Control }\end{array}$ & 2 & $7,900 \pm 400$ & $4.9 \pm 1.2$ \\
$\quad$ After maturation & & $7,800 \pm 400$ & $5.0 \pm 0.8$ \\
U937: & & & \\
$\quad$ Control & 3 & $4,000 \pm 1,200$ & $4.6 \pm 2.07$ \\
$\quad$ After induction & & $4,400 \pm 1,200$ & $3.9 \pm 0.96$ \\
HL60: & & & \\
$\quad$ Control & 2 & $3,600 \pm 800$ & $4.4 \pm 0.7$ \\
$\quad$ After induction (PMA) & & $3,400 \pm 1,000$ & $4.3 \pm 1.6$ \\
$\quad$ After induction (DMSO) & & $4,000 \pm 400$ & $4.5 \pm 1.1$
\end{tabular}

Maturation was induced in monocytes by culture in teflon beakers for 6 or $8 \mathrm{~d}$. Maturation in U937 was induced by culture with PMA for 5 d. The promyelocytic cell line HL60 was differentiated into monocytic cells by incubation with PMA or into granulocytic cells by incubation with DMSO. cytometer as described in Methods. Inset: Comparison of IFN $\gamma$ receptor occupancy and induction of $\mathrm{Fc}$ receptors. The IFN $\gamma$ input has been expressed in molarity and adjusted to $10^{6} \mathrm{cell} / \mathrm{ml}$.

Intracellular and extracellular distribution of IFN $\gamma$ receptors. Saponin and digitonin have been used by others to permeabilize cells, and allow quantitation of intracellular (or cryptic) and extracellular receptors $(18,19)$. In order to obtain these values

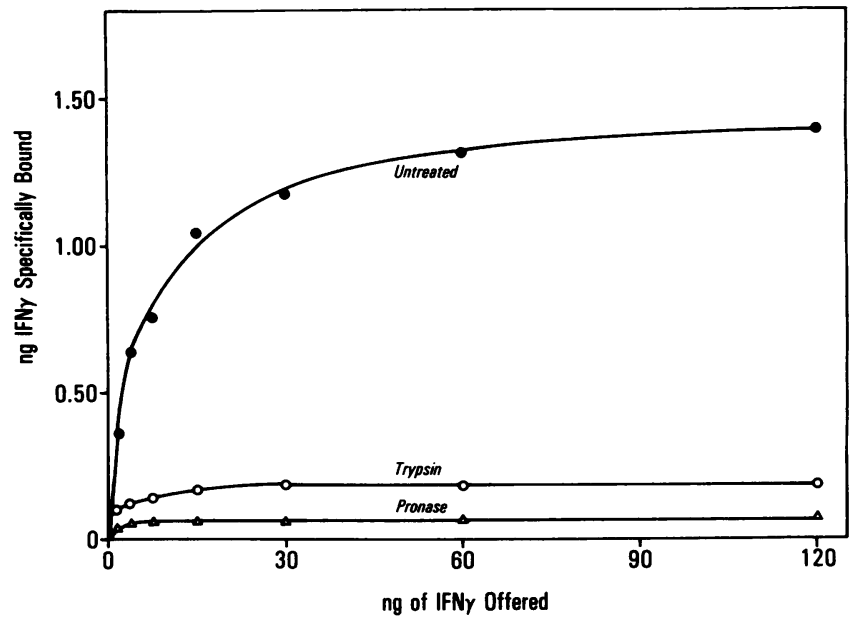

Figure 5. Effect of protease treatment on IFN $\gamma$ binding by U937 cells. Three sets of $50 \times 10^{6}$ cells were washed with EDTA and then incubated for $5 \mathrm{~min}$ with medium or $1 \mathrm{mg} / \mathrm{ml}$ of pronase or trypsin in a total volume of $50 \mathrm{ml}$. Cells were washed and IFN $\gamma$ binding studies were carried out as outlined in Fig. 1. 


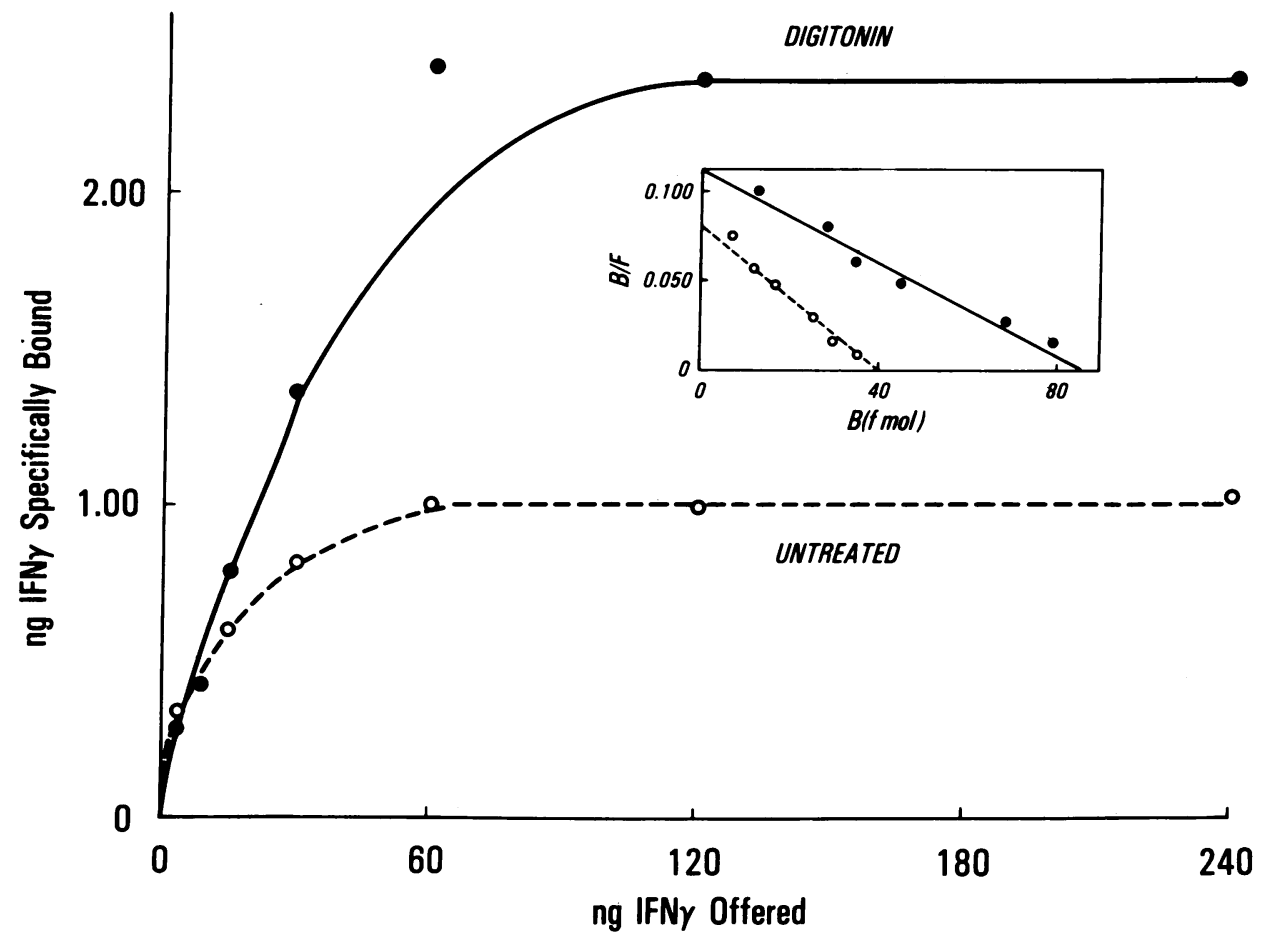

Figure 6. Binding of IFN $\gamma$ to U937 cells in the presence and absence of $0.055 \%$ digitonin. Cells $\left(5 \times 10^{6}\right)$ were incubated with ligand at $4^{\circ} \mathrm{C}$ for $2 \mathrm{~h}$ in a total volume of $1 \mathrm{ml}$. To one set of tubes, digitonin $(14 \mathrm{mg} / \mathrm{ml}$ in ethanol) was added to a final concentration of $0.055 \%$. Control tubes received an equivalent concentration of ethanol. The reaction was terminated by spinning the cells and counting the pellets and the supernatants. for the IFN $\gamma$ receptor, the binding studies were repeated on U937 with these agents. In the presence of $0.055 \%$ digitonin, U937 specifically bound 10,200 IFN $\gamma$ molecules per cell, while untreated U937 bound only 4,700 IFN $\gamma /$ cell (Fig. 6). Digitonin did not release prebound ${ }^{125} \mathrm{I}-\mathrm{IFN} \gamma$, indicating that the permeabilization procedure did not cause extraction of receptors. The binding affinity of the total receptor pool was comparable to the $K_{\mathrm{a}}$ values of only the external receptors. By calculation, the intracellular receptors were estimated to comprise $54 \%$ of the total cellular receptor pool. Similar values for the intracellular levels of receptor were obtained in two other experiments with digitonin ( 48 and $52 \%$ ) or when $0.5 \%$ saponin was used as the permeabilization agent.

Receptor-mediated internalization of IFNr. Whereas the binding of IFN $\gamma$ to U937 was homogeneous at $4^{\circ} \mathrm{C}$, it was bimodal at $37^{\circ} \mathrm{C}$ (Fig. 7, left). The lower affinity binding at $37^{\circ} \mathrm{C}$ $\left(1.7 \times 10^{9} \mathrm{M}^{-1}\right)$ was of similar magnitude to that observed at $4^{\circ} \mathrm{C}\left(3.0 \times 10^{9} \mathrm{M}^{-1}\right)$. In addition, a high affinity binding of IFN $\gamma$ to the cells was observed at the elevated temperature $\left(2.3 \times 10^{10} \mathrm{M}^{-1}\right)$.

The high affinity binding observed at $37^{\circ} \mathrm{C}$ appeared to be a result of ligand internalization and not expression of different classes of receptors. This conclusion was reached because $(a)$ purified U937 membranes bound IFN $\gamma$ with a single affinity at either $4^{\circ} \mathrm{C}\left(1.2 \times 10^{9} \mathrm{M}^{-1}\right)$ or $37^{\circ} \mathrm{C}\left(1.5 \times 10^{9} \mathrm{M}^{-1}\right)$ (Fig. 7, right); $(b)$ at either temperature, whole paraformaldehyde-fixed U937 displayed only a single binding affinity for ligand (0.9 $\times 10^{9} \mathrm{M}^{-1}$ at $4^{\circ} \mathrm{C}, 0.8 \times 10^{9} \mathrm{M}^{-1}$ at $37^{\circ} \mathrm{C}$ ); and $(\mathrm{c}) \mathrm{IFN} \gamma$ internalization could be directly demonstrated at $37^{\circ} \mathrm{C}$ (Table III). In this last study, monocytes bound $33 \%$ more ligand at $37^{\circ} \mathrm{C}$ than at $4^{\circ} \mathrm{C}$. When monocytes that had bound IFN $\gamma$ at $4^{\circ} \mathrm{C}$ were stripped of surface receptors by trypsin treatment, the number of cell-associated IFN $\gamma$ molecules decreased from 5,300 to $700 /$ cell. In contrast to this result, cells that had been exposed to ligand at $37^{\circ} \mathrm{C}$ maintained 2,300 molecules of ${ }^{125} \mathrm{I}-\mathrm{IFN} \gamma /$ cell after enzyme treatment. When Scatchard analysis was performed on the reaction mixtures before and after trypsin stripping, an apparent 12.5 -fold increase in the $K_{\mathrm{a}}$ was observed.

Degradation of internalized ${ }^{125} I-I F N \gamma$. The temperature dependent conversion of ${ }^{125} \mathrm{I}-\mathrm{IFN} \gamma$ to TCA soluble degradation products is shown in Fig. 8. At either $4^{\circ}$ or $37^{\circ} \mathrm{C}$, cellular uptake of radiolabeled ligand reached a maximum after $10 \mathrm{~min}$ and remained essentially unchanged for the next $3.5 \mathrm{~h}$. Maximum binding at $37^{\circ} \mathrm{C}(1.7 \mathrm{ng})$ was $30 \%$ greater than at $4^{\circ} \mathrm{C}(1.3$ ng) (data not shown). At $4^{\circ} \mathrm{C}$, no IFN $\gamma$ degradation was observed

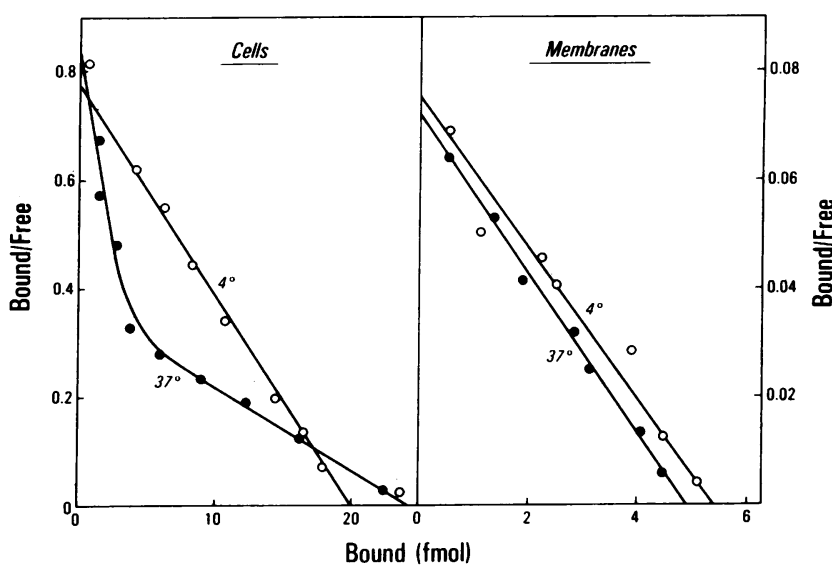

Figure 7. Effect of temperature on IFN $\gamma$ interaction with whole U937 cells and membranes. (Left) $\mathrm{U} 937$ cells $\left(5 \times 10^{6}\right)$ were incubated with ${ }^{125} \mathrm{I}-\mathrm{IFN} \gamma$ at $4^{\circ}$ or $37^{\circ} \mathrm{C}$ for $1 \mathrm{~h}$ in a total volume of $100 \mu \mathrm{l}$. Cell associated and free ligand were separated by centrifugation through pthalate oil. (Right) $200 \mu \mathrm{g}$ of purified U937 membranes were incubated at $4^{\circ} \mathrm{C}$ or $37^{\circ} \mathrm{C}$ for $1 \mathrm{~h}$ in a total volume of $100 \mu \mathrm{l}$. Free and membrane-bound radiolabeled IFN $\gamma$ were separated by ultracentrifugation. Nonspecific binding in both cases was determined by addition of 100 -fold excess of unlabeled IFN $\gamma$. 
Table III. Internalization of IFN $\gamma$ by Monocytes

\begin{tabular}{llcl}
\hline $\begin{array}{l}\text { Incubation } \\
\text { temperature }\end{array}$ & $\begin{array}{l}\text { Trypsin } \\
\text { stripping }\end{array}$ & IFN $\gamma$ molecules/cell & $\begin{array}{l}K_{\mathbf{a}} \times 10^{-8} \\
\left(\mathbf{M}^{-1}\right)\end{array}$ \\
\hline${ }^{\circ} \mathrm{C}$ & & & \\
4 & - & 5,300 & 4.7 \\
4 & + & 700 & 4.9 \\
37 & - & 7,000 & 4.1 \\
37 & + & 2,300 & 52.0 \\
\hline
\end{tabular}

$5 \times 10^{6}$ purified monocytes were adhered per well in six well tissue culture plates. Different amounts of IFN $\gamma$ were added to the plated monocytes in a total volume of $1 \mathrm{ml}$. Two sets of monocytes were incubated for $2 \mathrm{~h}$ at $4^{\circ} \mathrm{C}$ and another two at $37^{\circ} \mathrm{C}$. Then, one set of previously incubated monocytes at $4^{\circ} \mathrm{C}$ and another at $37^{\circ} \mathrm{C}$ were washed and treated with trypsin. The two other sets were only washed. Finally, 1\% NP40 was added, cells were lysed, and the radioactivity associated with the cells counted.

over the 4-h period (Fig. 8). However, TCA soluble radioactivity became detectable in culture supernatants of monocytes held at $37^{\circ} \mathrm{C}$ for $2 \mathrm{~h}$ and increased linearly for the next $2 \mathrm{~h}$. Based on the specific activity of the radioiodinated IFN $\gamma$, degradation was estimated to occur at a rate of 5,000 molecules/cell per $h$.

Characterization of the human monocyte IFN $\gamma$ receptor by $S D S-P A G E$. The data presented thus far defined the IFN $\gamma$ receptor of human mononuclear phagocytes by classical biochemical and functional criteria. We also wished to chemically define the receptor molecule. Initial attempts to directly radioiodinate the receptor on whole U937 cells and affinity purify it on IFN $\gamma$ coated beads were unsuccessful probably due to the limited number of receptor molecules expressed at the plasma membrane. However, since highly purified, radiolabeled ligand was available, we directed our efforts at affinity labeling the receptor by chemically cross-linking it to specifically bound ${ }^{125} \mathrm{I}-\mathrm{IFN} \gamma$. In preliminary experiments, cross-linking was confirmed by

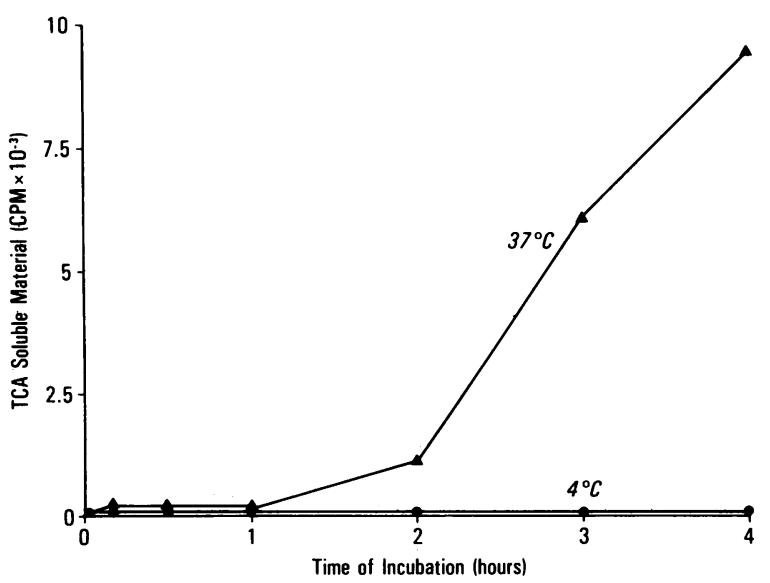

Figure 8. Degradation of IFN $\gamma$ by monocytes. $5 \times 10^{6}$ of elutriationpurified cells were adhered per well in six well tissue culture plates. $200 \mathrm{ng}$ of ${ }^{125} \mathrm{I}$-IFN $\gamma$ was added to each well and cultured at $4^{\circ} \mathrm{C}$ or $37^{\circ} \mathrm{C}$ for different periods of time. Then supernatants were harvested, mixed with FCS, and precipitated with TCA. TCA soluble and insoluble radioactivity was quantitated. Cells were washed, solubilized with $1 \%$ NP40, and radioactivity counted.

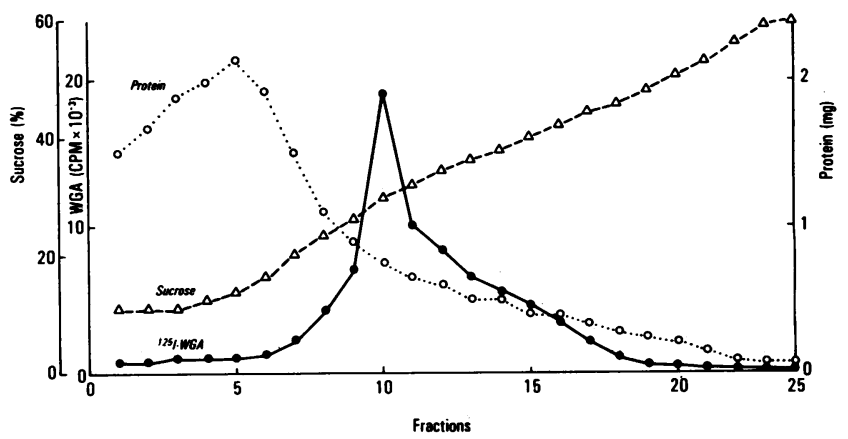

Figure 9. Purification of plasma membranes from U937 cells. Cells were prelabeled with ${ }^{125}$ I-WGA subjected to $\mathrm{N}_{2}$ cavitation, and purified by sucrose density gradient centrifugation for $1 \mathrm{~h}$ at $163,000 \mathrm{~g}$ The distribution of ${ }^{125} \mathrm{I}-\mathrm{WGA}$, protein, and sucrose is shown as a function of the relative volume collected from the sucrose density gradient.

demonstrating a reduction in the dissociation rate of ligand from the cell surface (data not shown).

In order to minimize the possibility of proteolysis of the ligand-receptor complex (and reduce nonspecific labeling), plasma membrane-enriched fractions were prepared from U937 cells by $\mathrm{N}_{2}$ cavitation and subsequent isopyknic sucrose density gradient sedimentation of the homogenate as outlined in the methods section. Plasma membrane recovery was determined by the presence of ${ }^{125} \mathrm{I}-\mathrm{WGA}$, which had been used in trace amounts to surface label the cells. $94 \%$ of the radioactivity applied to the gradients was sedimentable (total recovery was 95\%) and recovered as a single band with a peak at a density of $1.286 \mathrm{~g} /$ $\mathrm{cm}(30 \% \mathrm{wt} / \mathrm{vol}$ sucrose) (Fig. 9). This fraction carried $23 \%$ of the total ${ }^{125} \mathrm{I}-\mathrm{WGA}$ and only $5.6 \%$ of the total protein. Thereafter, the same fraction from gradients of unlabeled membranes was used as the membrane source.

Membrane preparations were incubated with ${ }^{125} \mathrm{I}-\mathrm{IFN} \gamma$, cross-linked, solubilized, and then analyzed by SDS-PAGE under reducing conditions. Fig. 10 depicts an autoradiograph of a

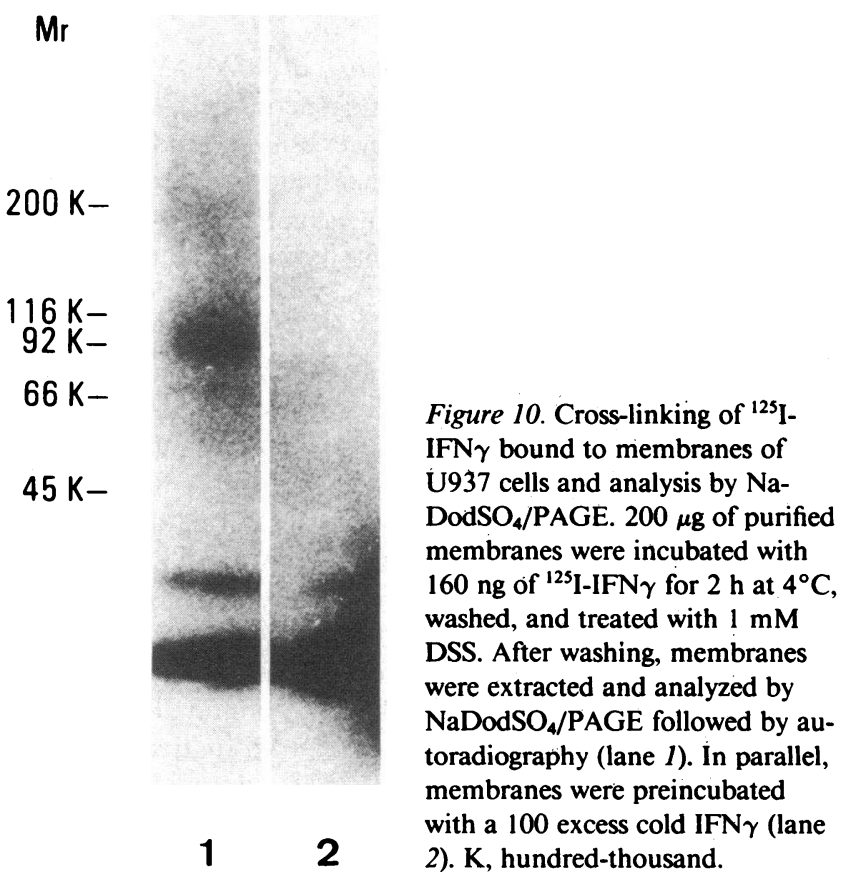


preparation cross-linked with $1 \mathrm{mM}$ disuccinimidyl suberate (DSS). The sample in lane 1 represents membranes that were reacted with labeled IFN $\gamma$. A wide radioactive band is visible with an $M_{\mathrm{r}}$ of 94,000 . This band has been observed in nine different experiments that used three different membrane preparations. The average $M_{\mathrm{r}}$ for the top and bottom portions of the band were $104,000 \pm 18,000$ and $84,000 \pm 6,000$, respectively. The band was not observed when the U937 membranes were pretreated with a 100-fold excess of unlabeld IFN $\gamma$ (Fig. 10, lane 2 ), when the radioiodinated ligand was preincubated with a monoclonal anti-IFN $\gamma$ (M125) that inhibited binding of IFN $\gamma$ to cell surfaces (data not shown) or when the cross-linking agent was omitted (data not shown).

The two bands at the bottom of both tracks display $M_{\mathrm{r}}$ of 17,000 and 34,000 , and are consistent with the presence of polypeptides, having molecular weights corresponding to a single IFN $\gamma$ polypeptide chain and an internally cross-linked polypeptide chain dimer. These bands appear in the presence or absence of unlabeled IFN $\gamma$ and are therefore presumed to be nonspecific and possibly represent free ligand carried through the washing procedure.

The high molecular weight band shows cross-linker selectivity. The band was observed only when DSS or EGS were used as linking agents but not when DMS was employed. DSS crosslinked preparations produced clearer autoradiographs than EGS samples. DSS cross-linking was dose dependent. At concentrations of $0.2 \mathrm{mM}$, no cross-linking occurred, while at high concentrations $(30 \mathrm{mM})$, the samples were so heavily cross-linked that they did not enter the SDS gel. Optimal results were obtained at $1 \mathrm{mM}$ linking agent.

In two experiments, whole U937 cells were used as the receptor source. The autoradiographs showed a complex band in which the $M_{\mathrm{r}}$ of the top was $107,000 \pm 10,000$ and was $87,000 \pm 700$ at the bottom. These results thus agree with those of the purified membrane preparations.

\section{Discussion}

The data presented in this report serve to define and partially characterize the IFN $\gamma$ receptor on human mononuclear phagocytes. These studies represent a detailed analysis of the receptor on this cell type and are particularly warranted because monocytes and macrophages represent a major target of the immunomodulatory actions of IFN $\gamma$. Binding of radioiodinated, purified recombinant human IFN $\gamma$ to human peripheral blood monocytes $\mathrm{U} 937$ and $\mathrm{HL} 60$ at $4^{\circ} \mathrm{C}$ was noncooperative, saturable, reversible, and of moderately high affinity $\left(K_{\mathrm{a}}=0.5-1.0\right.$ $\left.\times 10^{9} \mathrm{M}^{-1}\right)$. The interaction was specific because uptake of radiolabeled ligand was inhibited only by unlabeled natural or recombinant IFN $\gamma$ (and not IFN $\alpha$ or IFN $\beta$ ) or by monoclonal antihuman IFN $\gamma$, which blocked IFN $\gamma$-dependent antiviral activity. The mononuclear phagocyte receptor appeared to be a protein because IFN $\gamma$ did not bind to cells treated with trypsin or pronase. At $37^{\circ} \mathrm{C}$, surface-bound ligand was internalized and could not be eluted from the cells with trypsin. Intracellular IFN $\gamma$ was degraded into TCA-soluble material at a constant rate of $\sim 5,000$ molecules/cell per $h$.

When binding was performed at $37^{\circ} \mathrm{C}$, the Scatchard plot of the binding data was biphasic. This result could either indicate the presence of a second high affinity class of IFN $\gamma$ receptors as suggested by Aiyer et al. (28), or that ligand internalization had occurred. The first possibility was excluded by the demonstration that purified membranes and paraformaldehyde fixed U937 bound ligand in a unimodal manner at either $4^{\circ}$ or $37^{\circ} \mathrm{C}$.

Receptor expression and avidity were not influenced by cellular differentiation or activation, and even uncommitted precursor cells (such as HL60) carried IFN $\gamma$ receptors on their surface. This observation is compatible with the previously reported ability of IFN $\gamma$ to induce differentiation of precursor cells such as HL60 and U937 $(29,30)$, activate a variety of functions in mature human monocytes and macrophages (6), and cause terminal differentiation of monocytes to polykarions (31). Thus, the IFN $\gamma$ receptor appears to be a ubiquitous component of the mononuclear phagocyte plasma membrane. This conclusion distinguishes the IFN $\gamma$ receptor from $\mathrm{Fc}$ and $\mathrm{C} 3$ receptors, since the latter are expressed only on more differentiated forms of mononuclear phagocytes $(21,32)$.

The low magnitude of receptor expression on monocytes necessitated an indirect analysis approach to study the molecular weight of the receptor. Cross-linked preparations of radiolabeled ligand and purified plasma membranes migrated on SDS-PAGE as a wide band that spanned a molecular weight range of 87,000 104,000 . While this apparent heterogeneity may reflect a high level of receptor glycosylation, it is more likely that it results from the formation of a cross-linked complex between the membrane component and either the internally cross-linked whole IFN $\gamma$ molecule (consisting of two identical 17,000-mol wt polypeptide chains) or a single polypeptide chain subunit. Under the dissociating conditions used in the SDS-PAGE analysis, the complexes would therefore contain either a 34,000- or $17,000-M_{\mathrm{r}}$ ligand component. By subtracting these values from the apparent molecular weights at the top and bottom of the band, the molecular weight of the receptor is estimated to be 70,000 . The similarity of the molecular weight estimates made on different purified membrane preparations and whole cells suggests that receptor degradation did not occur during processing. However, the final assignment of a molecular weight for the IFN $\gamma$ receptor on mononuclear phagocytes must await an analysis of the free molecule after documentation of its ligand binding capability. Attempts are currently being made in our laboratory to achieve these goals.

Interferon- $\gamma$ induces a wide spectrum of biological activities in macrophages, including the induction of major histocompatibility complex class II antigens, Fc and C3bi receptors, cytocidal activity, and stimulation of ILl production (6). Binding of IFN $\gamma$ to. its cell surface receptor represents the first step in the induction of the various macrophage cellular responses. In our experiments, the concentration of IFN $\gamma$ needed to effect receptor occupancy closely correlated with that which induced Fc receptors on U937. Similar concentrations of IFN $\gamma$ have been reported by others to induce responses in U937 or monocytes. Perusia et al. (26) and Guyre et al. (27) needed between 1 and $50 \mathrm{ng}$ IFN $\gamma / \mathrm{ml}$ to induce $100 \%$ Fc receptor expression on U937 cells. Nathan et al. (33) reported that 1.2-nM concentrations of IFN $\gamma(40.8 \mathrm{ng} / \mathrm{ml})$ induced $50 \%$ of maximal toxoplasmacidal activity in monocytes. The latter experiments used human IFN $\gamma$ that displayed a specific activity of $6 \times 10^{5} \mathrm{U} / \mathrm{mg}$. Taken together, these results validate the biological relevance of the IFN $\gamma$ receptor.

Over a period of $4 \mathrm{~h}$, IFN $\gamma$ was degraded at a linear rate of $\sim 5,000$ molecules/cell per $h$. This means that the receptors on the cell surface need to be replaced three times during this time period. This data is consistent with our previous report (7), which showed a similar pattern of IFN $\gamma$ absorption by murine mac- 
rophages. It is clear from these calculations that additional receptors must be recruited to the cell surface during the course of incubation. These may be derived from $(a)$ a preexisting intracellular pool of receptors, $(b)$ recycling of internalized receptors after the dissociation of bound ligand, or (c) de novo synthesis of additional IFN $\gamma$ receptors. Increased receptor synthesis does not appear to be required, since cells treated with cycloheximide (a protein synthesis inhibitor) bound and degraded IFN $\gamma$ in a normal fashion (data not shown). Experiments using permeabilized cells demonstrated the presence of cryptic receptors equal in the number to the receptors at the cell surface. In studies to be presented elsewhere, receptor recycling was evidenced by the ability of lysosomotropic agents to inhibit degradation (Celada, A., and R. D. Schreiber, manuscript in preparation). It is of interest to note that murine macrophages must be kept in contact with IFN $\gamma$ for at least $4 \mathrm{~h}$ before tumoricidal activity can be initiated $(7,34-36)$. Similar observations have been reported for IFN $\gamma$-dependent induction of antiviral activity in fibroblasts (37). The possibility thus exists that ligand internalization may play a role in inducing certain cellular responses. However, other less complex functions, such as increased hydrogen peroxide production, appear to occur as a direct consequence of ligand-receptor interaction (33). Together, these results indicate that induction of complex biological functions in macrophages may require more than receptor-mediated signal transduction.

To date, an IFN $\gamma$ receptor has been detected on several different human cell types, including fibroblasts (38-41), lymphoblastoid cells (42), epitheloid cells (43), and, in preliminary reports, U937 (44) and monocytes (45). At the present time, the relationship between the IFN $\gamma$ receptors on these cells remains undefined. On the basis of the above studies, all cell types appear to carry comparable numbers of receptors $\left(10^{3}-10^{4} /\right.$ cell $)$ that display similar binding affinities at $4^{\circ} \mathrm{C}\left(K_{\mathrm{a}}=10^{8}-10^{9} \mathrm{M}^{-1}\right)$. The cross-linked IFN $\gamma$-IFN $\gamma$ receptor complex from WISH fibroblasts displayed an apparent molecular weight of 105,000 (40), and from lymphoblastoic cells, 125,000 (42). These values are comparable to the mean molecular weight of the U937-derived complex reported herein. Recent experiments, performed in our laboratory, which directly compared ligand binding to monocytes and fibroblasts, showed that IFN $\gamma$ bound to the two cell types with identical affinities $\left(K_{\mathrm{a}}=1.5\right.$ and $1.8 \times 10^{9} \mathrm{M}^{-1}$, respectively (Celada, A., and R. D. Schreiber, unpublished observation). Although this data suggests the presence of a single type of IFN $\gamma$ receptor on different cells, definitive conclusions must await a full biochemical and genetic analysis of the receptor.

The identification of an IFN $\gamma$ receptor on macrophages is the first step toward understanding macrophage activation at the molecular level. Work is currently in progress to fully characterize the receptor, determine its fate after receptor-ligand contact, and to assess whether receptor engagement is sufficient to initiate macrophage activation. These investigations should provide new insights into the role of IFN $\gamma$ and activated macrophages in host defense.

\section{Acknowledgments}

The authors are grateful to Dr. Algirdas Jesaitis of this institute for his help in membrane purification and helpful discussions during the preparation of this manuscript. They are also grateful for the expert technical assistance of Tracy Dale, Lori Hicks, Virginia Keivens, and Pamela Skeen.

This work was supported by U. S. Public Health Service grants CA 34120 and AI 17354 and by grants from Eli Lilly \& Co. (Indianapolis,
IN) and the Elsa U. Pardee Foundation. Dr. Gray was supported by Genentech, Inc.

\section{References}

1. North, R. J. 1978. The concept of activated macrophage. J. Immunol. 121:806-809.

2. Karnovsky, M. L., and J. K. Lazdins. 1978. Biochemical criteria for activated macrophages. J. Immunol. 121:809-813.

3. Cohn, Z. A. 1978. The activation of mononuclear phagocytes: fact, fancy and future. J. Immunol. 121:813-816.

4. Rocklin, R. E., K. Bendtzen, and D. Greineder. 1980. Mediators of immunity: lymphokines and monokines. Adv. Immunol. 29:56-136.

5. Schreiber, R. D., and A. Celada. 1985. Molecular characterization of gamma interferon as a macrophage activating factor. Lymphokines. 11:87-118.

6. Vilcek, J., P. W. Gray, E. Rinderknecht, and C. G. Sevastopoulos. 1985. Interferon-gamma: a lymphokine for all seasons. Lymphokines. 11:1-46.

7. Celada, A., P. W. Gray, E. Rinderknecht, and R. D. Schreiber. 1984. Evidence for a gamma-interferon receptor that regulates macrophage tumoricidal activity. J. Exp. Med. 160:55-74.

8. Schreiber, R. D., L. J. Hicks, A. Celada, N. A. Buchmeier, and P. W. Gray. 1985. Monoclonal antibodies to murine gamma interferon which differentially modulate macrophage activation and antiviral activity. J. Immunol. 134:1609-1618.

9. Schreiber, R. D., A. Altman, and D. H. Katz. 1982. Identification of a $\mathrm{T}$ cell hybridome which produces large quantities of macrophageactivating factor. J. Exp. Med. 156:677-689.

10. Blalock, J. E., J. A. Georgiades, M. P. Langford, and H. M. Johnson. 1980. Purified human immune interferon has more potent anticellular activity than fibroblast or leukocyte interferon. Cell Immunol. 49:390-394.

11. Gray, P. W., D. W. Leung, D. Pennica, E. Yelverton, R. Najarian, C. Simonsen, R. Derynck, P. J. Sherwood, D. M. Wallace, S. L. Berger, A. D. Levinson, and D. Goeddel. 1982. Expression of human immune interferon cDNA in E. Coli and monkeys cells. Nature (Lond.). 295: 503-508.

12. Pangburn, M. K., R. D. Schreiber, and H. J. Müller-Eberhard. 1983. Deficiency of an erythrocyte membrane protein with complement regulatory activity in paroxysmal nocturnal hemoglobinuria. Proc. Natl. Acad. Sci. USA. 80:5430-5434.

13. Kaplow, L. S. 1965. Simplified myeloperoxidase staining using benzidine dihydrochloride. Blood. 26:215-219.

14. Sundstrom, C., and K. Nilsson. 1976. Establishment and characterization of a human histiocytic lymphoma cell line (U-937). Int. J. Cancer. 17:565-577.

15. Collins, S. J., R. C. Gallo, and R. E. Gallagher. 1977. Continuous growth and differentiation of human myeloid leukaemic cells in suspension culture. Nature (Lond.). 270:347-349.

16. Jesaitis, A. J., J. R. Naemura, R. G. Painter, L. A. Sklar, and C. G. Cochrane. 1982. Intracellular localization of $\mathrm{N}$-formyl chemotactic receptor and $\mathrm{Mg}^{2+}$ dependent ATPase in human granulocytes. Biochim. Biophys. Acta. 719:556-568.

17. Jesaitis, A. J., J. R. Naemura, R. G. Painter, L. A. Sklar, and C. G. Cochrane. 1983. The fate of an $\mathrm{N}$-formylated chemotactic peptide in stimulated human granulocytes. Subcellular fractionation studies. $J$. Biol. Chem. 258:1968-1977.

18. Weigel, P. H., and J. A. Oka. 1983. The large intracellular pool of asialoglycoprotein receptors functions during the endocytosis of asialoglyco-proteins by isolated rat hepatocytes. J. Biol. Chem. 258:50955102.

19. Fischer, H. D., A. Gonzalez-Noriega, W. S. Sly, and D. J. Morre. 1980. Phosphomannosyl-enzyme receptors in rat liver. Subcellular distribution and role in intracellular transport of lysosomal enzymes. $J$. Biol. Chem. 255:9608-9615. 
20. Lowry, O. H., N. J. Rosebrough, A. L. Farr, and R. J. Randall. 1951. Protein measurement with folin phenol reagent. J. Biol. Chem. 193:265-275.

21. Wright, S. D., and S. C. Silverstein. 1982. Tumor-promoting phorbol esters stimulate $\mathrm{C} 3 \mathrm{~b}$ and $\mathrm{C} 3 \mathrm{~b}^{\prime}$ receptor mediated phagocytosis in cultured human monocytes. J. Exp. Med. 156:1149-1164.

22. Radzun, H. J., M. R. Parwaresch, C. Sundstrom, K. Nilsson, and M. Eissner. 1983. Monocyte origin of the human hematopoietic cell line U-937 and its convertibility to macrophages evidenced by isoenzyme mapping. Int. J. Cancer. 31:181-186.

23. Rovera, G., D. Santoli, and C. Damsky. 1979. Human promyelocytic leukemia cells in culture differentiate into macrophage-like cells when treated with a phorbol diester. Proc. Natl. Acad. Sci. USA. 76: 2779-2783.

24. Collins, S. J., R. F. Ruscetti, R. E. Gallagher, and R. C. Gallo. 1978. Terminal differentiation of human promyelocytic leukemic cells induced by dimethyl sulfoxide and other polar compounds. Proc. Natl. Acad. Sci. USA. 75:2458-2462.

25. Laemmli, U. K. 1970. Cleavage of structural proteins during the assembly of the head of bacteriophage T4. Nature (Lond.). 227:680-685.

26. Perussia, B., E. T. Dayton, R. Lazarus, V. Fanning, and G. Trinchieri. 1983. Immune interferon induces the receptor for monomeric IgGl on human monocytic and myeloid cells. J. Exp. Med. 158:10921113.

27. Guyre, P. M., P. M. Morganelli, and R. Miller. 1983. Recombinant immune interferon increases immunoglobulin G Fc receptors on cultured human mononuclear phagocytes. J. Clin. Invest. 72:393-397.

28. Aiyer, R. A., L. E. Serrano, and P. P. Jones. 1985. High-affinity receptors for murine interferon-gamma on mouse macrophages. Fed. Proc. 44:785. (Abstr.)

29. Buessow, S. C., and G. Y. Gillespie. 1984. Interferon- $\alpha$ and $-\gamma$ promote myeloid differentiation of HL-60, a human acute promyelocytic leukemia cell line. J. Biol. Resp. Modif. 3:653-662.

30. Hattori, T., M. Pack, P. Bougnoux, Z. L. Chang, and T. Hoffman. 1983. Interferon-induced differentiation of U937 cells. Comparison with other agents that promote differentiation of human myeloid or monocyte like cell lines. J. Clin. Invest. 72:237-244.

31. Weinberg, J. B., M. M. Hobbs, and M. A. Misukonis. 1984. Recombinant human $\gamma$ interferon induces human monocyte polykaryon formation. Proc. Natl. Acad. Sci. USA. 81:4554-4557.

32. Fleit, H. B., S. D. Wright, C. J. Durie, J. E. Valinsky, and J. C. Unkeless. 1984. Ontogeny of Fc receptors and complement receptor (CR 3) during human myeloid differentiation. J. Clin. Invest. 73:516525.
33. Nathan, C. F., H. W. Murray, M. E. Wiebe, and B. Y. Rubin 1983. Identification of interferon- $\gamma$ as the lymphokine that activates human macrophage oxidative metabolism and antimicrobial activity. $J$. Exp. Med. 158:670-689.

34. Marino, P. A., and D. O. Adams. 1982 . The capacity of activated murine macrophages for augmented binding of neoplastic cells: analysis of induction by lymphokine containing MAF and kinetics of the reaction. J. Immunol. 128:2816-2823.

35. Meltzer, M. S., M. Occhionero, and L. P. Ruco. 1982. Macrophage activation for tumor cytotoxicity: regulatory mechanisms for induction and control of cytotoxic activity. Fed. Proc. 41:2198-2205.

36. Occhionero, M., E. J. Leonard, and M. S. Meltzer. 1984. Functional characterization of lymphokines from the EL-4T cell line that activate macrophages for nonspecific tumor cytotoxicity. J. Leuk. Biol. 35:405-414.

37. Dianzani, F., L. Salter, W. R. Fleishmann, and M. Zucca. 1978. Immune interferon activates cells more slowly than does virus-inducted interferon. Proc. Soc. Exp. Biol. Med. 159:94-97.

38. Anderson, P., Y. K. Yip, and J. Vilcek. 1982. Specific binding of ${ }^{125}$ I human interferon- $\gamma$ to high affinity receptors on human fibroblasts. J. Biol. Chem. 257:11301-11304.

39. Anderson, P., Y. K. Yip, and J. Vilcek. 1983. Human interferon $\gamma$ is internalized and degraded by cultured fibroblasts. J. Biol. Chem. 258:6497-6502.

40. Sarkar, F. H., and S. L. Gupta. 1984. Receptors for human $\gamma$ interferon: binding and cross-linking of ${ }^{125}$-labeled recombinant human $\gamma$ interferon to receptors on WISH cells. Proc. Natl. Acad. Sci. USA. 81: $5160-5164$.

41. Orchansky, P., D. Novick, D. G. Fischer, and M. Rubinstein. 1984. Type I and Type II interferon receptors. J. Interferon Res. 4:275282

42. Littman, S. J., C. R. Faltynek, and C. Baglioni. 1985. Binding of human recombinant ${ }^{125}$ I-interferon $\gamma$ to receptors on human cells. $J$. Biol. Chem. 260:1191-1195.

43. Thompson, M. R., Z. Zhang, A. Fournier, and Y. H. Tan. 1985. Characterization of human $\beta$-interferon-binding sites on human cells. J. Biol. Chem. 260:563-567.

44. Rashidbaigi, A., H. F. Kung, and S. Pestka. 1985. Study of the receptor for immune interferon in human histiocytic lymphoma U937 cells with a ${ }^{32} \mathrm{P}$-labeled human recombinant immune interferon. Fed. Proc. 44:1435. (Abstr.)

45. Finbloom, D. B., D. Hoover, and L. Wahl. 1985. Binding of human recombinant interferon gamma (rIFN) to its receptor on human monocytes and U937 and HL60 cell lines. Arthritis Rheum. 28:S19. (Abstr.) 